\title{
Psychological meaningfulness at work as a mediator of job characteristic and job attachment in public elementary schools in Yogyakarta
}

\author{
Welly Putri Akmadelita ${ }^{1}$; Erika Setyanti Kusumaputri ${ }^{2}$ \\ Department of Psychology, Universitas Islam Negeri Sunan Kalijaga Yogyakarta, Jl. Laksda Adisucipto, \\ Depok, Sleman, Yogyakarta 55281, Indonesia ${ }^{1,2}$ \\ welly.akmadelita@gmail.com¹ ${ }^{1}$; rikakusumaputri@yahoo.co.id ${ }^{2}$
}

\begin{abstract}
This study aims to determine the relationship between job characteristics toward work engagement through the mediating psychological meaningfulness. Subjects in this study were a primary school teacher in Yogyakarta who totaled $132(\mathrm{~N}=132)$ of teachers. Our data was collected using the work engagement scale (vigor, dedication, and absorption), job characteristics scale (skill variety, task identity, task significance, autonomy, and feedback), and psychological meaningfulness scale (meaningful work, others around the work environment, the work context, and spiritual life) - the methods of data analysis used path analysis techniques developed from regression analysis. Results of path analysis indicated that indirect effect was significant $(\mathrm{p} 20.332 \times 0.332=0.110)$ and the direct effect of 0511 . Therefore, the total effect of the work engagement is direct and indirect effect that is $0.511+0.110=0.621(62.1 \%)$. This means that hypotheses were accepted, there is a correlation between job characteristics toward work engagement through psychological meaningfulness as a mediator, where the suitability of job characteristics will improve work engagement through psychological meaningfulness as a mediator, where the suitability of job characteristics will improve work engagement through psychological meaningfulness that also higher on the teacher.
\end{abstract}

Keywords: work engagement, job characteristics, psychological meaningfulness, path analysis

\section{Introduction}

Job attachment is the motivation and center of positive thoughts that are linked to work that is characterized by many aspects, such as spirit and energy (vigor), dedication or pride, commitment to a job (dedication), and also appreciation (absorption) (Schaufeli \& Bakker, 2004). According to Smulders (in Hadi \& Indriyanti, 2012), some of the jobs that demand high job attachment are educator, manager, entrepreneur, actor, doctor, and nurse. These jobs have something in common, which is involving quality of service as the primary capital.

Workers with a high job attachment tend to show their best performance, give their maximum, and exceed what has been targeted by the organization. This is because they enjoy the work that they do (Bakker, 2010). Robbins (2011) states that a teacher who has a good job attachment can influence the achievement of organization goals because he/she will side and care about the field of work that he/she does.

The reality today shows that as we face globalization, some teachers tend to have low job attachment. The problem that often arises in an organization is that some teachers commit interdisciplinary violations, such as absence in an organization, lack of spirit in teaching, and low dedication at work or the profession as a teacher, which indicate low job attachment in doing their job (Schaufeli \& Bakker, 2009).

Low job attachment in teachers can also be found in a public elementary school in Balikpapan. This is seen from the behavior of teachers that lacks discipline at work, such as coming into class much later than the schedule, leaving school before the class is over, leaving school without following the applicable rule and procedures, and also lacking passion in teaching which cause ineffectiveness in achieving the school's organization goals (Rusnawati, 2013). 
The National Ministry of Education (MoE) quotes that $40 \%$ of teachers who pass the certification have a standard score below five points. This means that in many cases, the quality stays the same despite teachers receiving educator profession allowance (TPP) granted by the certification. 'Only 29.6 percent increase is seen in teacher's competence after certification and TPP allocation,' says Salamun. The percentage of success in completing the teacher's certification for increased quality is only $50 \%$. Meanwhile, the number of the teacher's welfare is $60 \%$ (www.republika.co.id). A person's competence in the workplace is strongly linked to that person's job attachment; the lower the competence, the lower the spirit to work and bad work quality is an indicator of low job attachment (Bakker \& Leiter, 2010).

A member of Education Care Community Forum (Formas Pepak), Abdul Muslih, mentions (in Suara Merdeka, 26 November 2013) that the teacher's certification is completed by all means to claim the allowance every month. Sometimes they even choose to leave their students during school time to take care of certification requirements, teaching matters which happen to be their primary responsibilities are not completed well. Their performance and competence are inferior to private teachers who are paid below the regency minimum wage (or Upah Minimum $\mathrm{Ka}$ bupaten - UMK) (www.suaramerdeka.com).

In the JD-R (job demands-resources model), it is explained that Job resource is one of the factors of job attachment that shows that several things are behind the understanding of job attachment, one of which is job characteristic. This is consistent with the researches conducted by Shaufeli and Bakker (2003) and Rothman (2010) which show that one of the factors influencing job attachment is job characteristic. A job characteristic that fits the worker can affect the meaningfulness felt by the worker, thus altering job attachment of their roles.

The above arguments are further supported by research done by Hackman and Oldham (1990), which explains the factor job characteristic that is related to psychological condition and worker's interests. Job charac- teristic determines the suitability of a person with a particular field of work and allowing this person to be more successful in the area of work that he/she pursues.

Job characteristic is an internal aspect of a job that refers to the contents and conditions of a job. Efforts to identify characteristics of the tasks in the job, how these characteristics are combined to create a different position, become interesting and also create meaning in workers. Job characteristic according to Oldham (1990) consists of five aspects, namely variety of skills, task identity, the meaning of task, autonomy, and feedback; the achievement of which also influence psychological condition such as psychological meaningfulness.

Psychological meaningfulness is a condition that is felt by a person when he/she feels useful and content, the feeling of being given power over a specific task that is in line with his/her goals. The results of this research explain that the condition can appear when a person has a clear understanding of his/herself, knowing the hopes and desires from a particular job, as well as how to achieve success in the work environment (Bains, 2010; Steger \& Dik, 2009; Steger \& Dik, 2010).

Job attachment is affected by several aspects: spirit, strength or energy (vigor), dedication or pride toward job (dedication), commitment and difficulty in leaving job (absorption) (Schaufeli, Salanova, Gonzales-Roma, \& Bakker, 2002; May, Gilson \& Harter, 2004; Cook, 2008; Bakker, Schaufeli, Leiter, \& Taris, 2008).

Research by Indidjastuti (2011) finds that a person whose job involves skill variation, job identity, and task significance will consider his/her job meaningful. A high level of autonomy will create a bigger responsibility, and when sufficient feedback is given, the employee will develop an understanding that he/she is functioning, obtaining meaning and motivated and content. When a worker has characteristics that match the job's, then psychological meaningfulness that is felt will be felt greater. Consequently, when an employee is content and meaningful regarding his/her career, then he/she will have a better attachment to the job. 
Based on the afore-mentioned explanation, the hypothesis in this research is that there is a relationship between job characteristic and job attachment, that is mediated by psychological meaningfulness. Job characteristic that is in line with the worker will increase job attachment through psychological meaningfulness that is also higher. Meanwhile, a mismatch in job characteristic will lower job attachment through psychological meaningfulness that is even lower.

\section{Method}

\section{Research Subject}

The population selected in this research is the civil servants teaching staff of a public elementary school in Yogyakarta. Based on a table by Krejcie and Morgan (in Sekaran, 1992), with a population of 288 and a technique of cluster random sampling, the number of the sample needed is 165 people.

\section{Data Collection Method}

Measurement was done using three scales with answer options of Strongly Agree (SA), Agree (A), Neutral (N), Disagree (D), and Strongly Disagree (SD), with those scales having both favorable and unfavorable statements. The first scale consists of 24 items that refer to job attachment of Schaufeli, Salanova, Gonzales-Roma, and Bakker (2002), including spirit, strength or energy (vigor), dedication or pride toward work (dedication), commitment, and difficulty leaving job (absorption). The second scale consists of 40 items that refer to job aspects proposed by Hackman and Oldham (1990), including: skill variation, task identity, task significance, autonomy and feedback. The third scale is psychological meaningfulness that has 32 items, referring to aspects of psychological meaningfulness by Rosso, Dekas, and Wrzesniewski (2010), including: meaningful job, people around the workplace, job context and spiritual life.

\section{Data Analysis Method}

Data analysis used in the study was path analysis. This method was chosen to test the effect of the mediating variable on the cau- sality between the variables that are previously determined by theory (Ghozali, 2011). The formula is as follows:

$23=32 \quad 22+2232+22 \quad 32$

To calculate the $\mathrm{t}$-value, the formula used is:

$$
=\begin{array}{ll}
2 & 3 \\
2 & 3
\end{array}
$$

Description:

Sp : Standard error of the coefficient indirect effect

P2: Path between mediator and independent variable $(\mathrm{X})$

P3: Path between mediator and dependent variable $(\mathrm{Y})$

$t \quad$ : $t$-value of the mediating effect.

\section{Findings and Discussion}

Findings

\section{Subject Description}

Based on the subject categorization on the scale of job attachment, it is identified that none of the subjects fall under the 'very low', 'low', and 'medium' categories ( $0 \%), 56$ subjects $(42.4 \%)$ have high job attachment, and $76(57.6 \%)$ have very high job attachment. Therefore, it can be concluded that public elementary school students in Yogyakarta have a very high job attachment, which is $57.6 \%$, especially those with the civil servant status.

Categorization of subjects on the scale of job characteristic yields $0 \%$ subjects with 'very low' and 'low' four subjects (3.03\%) with 'medium.' Furthermore, 63 subjects $(47.73 \%)$ have 'high' job attachment, and 65 subjects $(49.24 \%$ ) have 'very high' job characteristic. Therefore, it indicates that elementary school teachers in Yogyakarta have very high job characteristic, which is $49.24 \%$, especially those with the civil servant status.

Subject categorization on the psychological meaningfulness scale shows that no subjects $(0 \%)$ are categorized as having 'low' and 'very low' psychological meaningfulness, six subjects $(4.54 \%)$ have 'medium' psychological meaningfulness. Moreover, 71 subjects $(53.79 \%)$ have 'high' psychological meaningfulness, and 55 subjects $(41.67 \%)$ have 'very high' psychological meaningfulness. Thus, it indicates that public elementary school teach- 
ers in Yogyakarta have a very high psychological meaningfulness, at $53.79 \%$, particularly those with the civil servant status.

\section{Assumption Testing Results}

The data analysis from the normality distribution testing in this research used Kolmogrov Smirnov analysis technique using SPSS 16.0 for Windows, which shows that job attachment is distributed normally with a KS$Z$ score of 0.871 ( $p>0.05)$, job characteristic has a KS-Z score of 1.302 ( $\mathrm{p}>0.05)$ and psychological meaningfulness achieved a score of KS-Z $=0.874$ ( $p>0.05)$. Linearity testing uses test for linearity yielding $F=16.525(p<0.05)$ for the linearity of job characteristic - psychological meaningfulness, a score of $\mathrm{F}=42.782$ $(p<0.05)$ for the linearity of psychological meaningfulness - job attachment, and a score of $F=84.634(p<0.05)$ for the linearity of job characteristic - job attachment.

\section{Hypothesis Test Results}

Data analysis results indicate that job characteristic has direct influence on the endogenous variable job attachment of 0.511 $(p<0.05)$ and indirect effect of $0.110(p<0.05)$. Furthermore, it is understood that the effect of job characteristic on psychological meaningfulness is $11 \%$ and psychological meaningfulness contributes $48.3 \%$ toward job attachment. Moreover, the total effect of $62.1 \%$ indicates that job characteristic and psychological meaningfulness play a big role toward increasing teacher job attachment, therefore the proposed hypothesis is accepted. This shows that there is a significant positive relationship between job characteristic and job attachment, mediated by psychological meaningfulness. The higher the job characteristic that is felt by the teacher, the higher the job attachment will be, through psychological meaningfulness. The model based on path analysis results can be seen in the diagram presented in Figure 1.

\section{Discussion}

Research results on public elementary school teachers in Yogyakarta reveal that there is a relationship between job characteristic and job attachment through psychological meaningfulness, and it is significant. This is shown by the path analysis results of indirect effect coefficient of $0.110 \quad(p<0.05)$, which means that the confidence level is $5 \%$. The consequence is that psychological meaningfulness can mediate the relationship between job characteristic and job attachment. There is a significant mediating effect shown by psychological meaningfulness on the relationship between job characteristic and job attachment.

An effect of $62.1 \%$ indicates that job characteristic and psychological meaningfulness play a significant role in increasing job attachment of teachers. Furthermore, the other $37.9 \%$ is the effect of other variables outside of job characteristic and psychological meaningfulness.

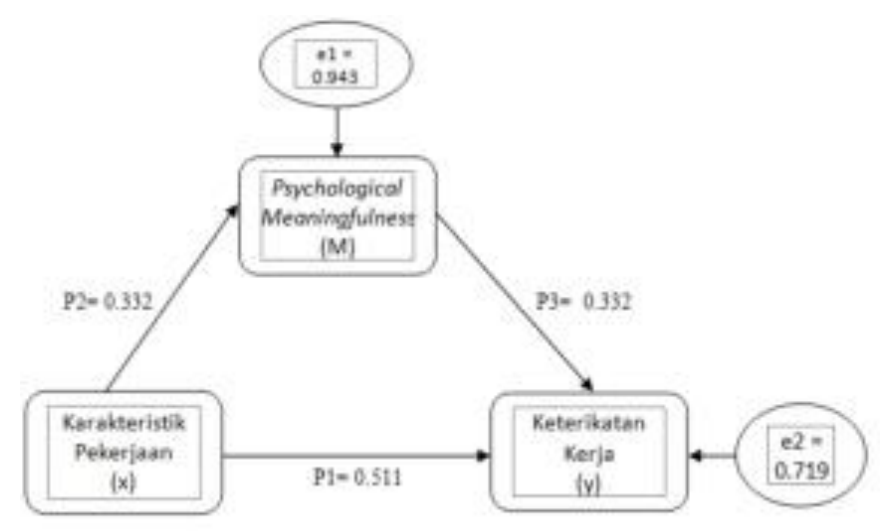

Figure 1. Path analysis intervariable results model between variable 
May, Gilson, and Harter (2004) explain that roles, work policies and activities that are in line with the concept of self-individual, have a strong relationship with psychological meaningfulness, which will have a positive effect on individual job attachment. Personal meaningfulness that appears is due to job characteristic that is consistent with goals, hopes, and self-value, forming meaningfulness in the individual, which leads to a better job attachment.

The match of job characteristic can influence the meaningfulness felt by a person. A job characteristic that goes in line with a person's psychological condition is considered valuable to him/her, creating a deep meaning that sparks the spirit to work, increasing responsibility and job quality, feeling difficult to be separate formwork. This is because the job is already considered a part of the meaning of life when a person feels high psychological meaningfulness, then job attachment will increase. High spirits, feeling proud of the job, and finding difficulties in separating himself from work are the characteristics of someone who has high job attachment. In line with the research results by May, Gilson, and Harter (2004), job characteristic (Hacman \& Oldham, $1980)$ is related to attachment through meaningfulness. The above discussion explains that job characteristic consists of the aspects of skill diversity, task identity, task meaning, autonomy, and feedback, which can increase psychological meaningfulness.

Job attachment of teachers increases when there is a job characteristic that is suitable with themselves, where the skills that they have can be utilized on multiple strategies in completing tasks, having freedom in controlling the execution and completion of a task, also producing good quality work. As explained by Hackman and Oldham (1990), job characteristic determines a person's suitability with a field of work and allows that person to be more successful in the field of study that he/she does. Teachers who feel high suitability with their jobs are more excited in teaching and teaching with all their appreciation; they also have a high dedication. This shows that teachers have a high job attachment (Schaufeli \& Salanova 2007).

\section{Conclusion and Recommendations}

\section{Conclusion}

Based on the analysis and discussion, it is concluded that there is a significant positive relationship between job characteristic and job attachment mediated by psychological meaningfulness. The higher the job characteristic, the higher the job attachment will be, through a higher psychological meaningfulness. Job characteristic has a direct effect on job attachment of $0.511(51.1 \%)$ and indirect effect of $0.110(11 \%)$. Furthermore, it is understood that the effective contribution of job characteristic on psychological meaningfulness is $11 \%$ and psychological meaningfulness contributes $48.3 \%$ to job attachment, effectively. A total score of $62.1 \%$ means that job characteristic and psychological meaningfulness play a big role in increasing teacher job attachment, and the other $37.9 \%$ is explained by other variables not explained by job characteristic and psychological meaningfulness.

\section{Recommendations}

Several recommendations can be given based on the results of this research: Firstly, for the school as the educational institution, since it is found in this study that job characteristic can increase job attachment through psychological meaningfulness, then the school needs to pay attention to the job characteristic taken by the teacher to increase psychological meaningfulness, that impacts how high the job attachment is, by, for instance, giving the teachers freedom to plan, execute, and conclude, as well as by not ignoring the rules. The next one is about paying attention to performance feedback that teachers need. It can also be done by building a group work system, which demands teachers to be more committed and involved in the task completion.

Secondly, public elementary school teachers are expected to build and observe a positive work climate (e.g., giving help and support for other teacher colleagues, submitting the best work to be useful for other people, providing accurate feedback to create an impact toward job attachment that is high through spirit, dedication, and appreciation of work). 
Thirdly, the recommendation is addressed to future researchers. Studies on job attachment are usually linked to job satisfaction, motivation and turnover. Thus, the researchers hope that more studies in the future review the references supporting this research or expand it by considering other factors that may influence job attachment or factors related to job characteristics. This research was done on elementary school students and on teachers who are civil servants; thus, future research can repeat this research in other stages of education, such as middle school and high school and in other professions other than teaching. Future research can also utilize other methods such as qualitative and experimental.

\section{References}

Agung, P. (2003). Pengaruh kompensasi dan karakteristik perkerjaan terhadap kepuasan kerja karyawan unit produksi PT. X Palembang. Jurnal Manajemen \& Bisnis Sriwijaya, 1(2), 1-21.

Agustian (2012). Pengaruh kompensasi, status/pengakuan, dan kesempatan berkembang terhadap tingkat employee engagement pada karyawan Universitas Sanata Dharma. Tesis (tidak diterbitkan). Yogyakarta: Magister Manajemen Universitas Gadjah Mada.

Arnold, K. A., Turner, N., Barling, J., Kelloway, E.K., \& McKee, M.C. (2007). Transformational leadership and psychological well-being: The mediating role of meaningful work. Journal of Occupational Health Psychology, 1(12), 193203.

Azwar, S. (2010). Penyusunan skala psikologi. Yogyakarta: Pustaka Pelajar.

Azwar, S. (2011). Reliabilitas dan validitas. Yogyakarta: Pustaka Pelajar.

Azwar, S. (2011). Tes prestasi. Yogyakarta: Pustaka Pelajar.

Bakker, A. B., Schaufeli, W. B., Leiter, M. P., \& Taris, T. W. (2008). Work engagement: An emerging concept in occupational health psychology. Journal of Organizational Behavior, 1 (22),187-200.

Bakker, A. B., Schaufeli, W. B., Leiter, M. P. (2010). Work engagement: $A$ bandbook of essential theory and research. Psychology Press.

Bakker, A. B., Tims, M., Derks, D. (2012). Proactive personality and job performance: The role of job crafting and work engagement. Human Relations, 6(10), 1359-1378.

Bakker, A. B. \& Xanthopoulo, D. (2013). Creativity and charisma among female leaders: The role of resources and work engagement. Journal of Human Resource Management, 24(14), 2760-2779.

Djastuti, I. (2011). Pengaruh karakteristik pekerjaan terhadap komitmen organisasi karyawan tingkat managerial perusahaan jasa konstruksi di Jawa Tengah. Jurnal Bisnis dan Akuntansi, 13(1), 1-19.

Ghozali, I. (2007). Aplikasi analisis multivariate dengan program SPSS. Semarang: Badan Penerbit Univeristas Diponegoro.

Hackman, J. R., Oldham, G., Janson, R., \& Purdy, K. (1975). A new strategy for job enrichment. California Management Review, 17(4), 1-57.

Indrianti, R. \& Hadi, C. (2012). Hubungan antara modal psikologis dengan keterikatan kerja pada perawat di instalasi rawat inap rumah sakit jiwa Menur Surabaya. Jurnal Psikologi Industri dan Organisasi, 1(3), 120- 125.

Isaksen, J. (2000). Constructing meaning despite the drudgery of repetitive work. Journal of Humanistic Psychology, 1(40), 116.

Kahn, W. A. (1990). Psychological conditions of personal engagement and disengagement at work. Academy of Management Journal, 33(4), 692-724.

Lightsey, O., \& Boyraz, G. (2011). Do positive thinking and meaning mediate the positive affect: life satisfaction 
relationship?. Canadian Journal Science, 43(3), 210-218.

Lockwood, N. R. (2007). Leveraging employee engagement for competitive advantage, SHRM research briefly stated, retrieved from http://www.shrm.org.htm on 15 December 2014

Maslach, C., Schaufeli, W. B., \& Leiter, M. P. (2001). Job burnout. Annual Review Of Psychology, 1(52), 397-422.

Maslach, C., Schaufeli, W. B., \& Leiter, M. P. (2008). Early predictors of Job Burnout and engagement. Journal of Applied Psychology, 93(3), 498-512.

May, D. R., Gilson, R. L., \& Harter, L. M. (2004). The Psychological conditions of meaningfulness, safety, and availability and the engagement of the human spirit at work. Journal of Occupational and Organizational Psychology, 77(1), 11-37.

Munandar, A. S. (2001). Psikologi industri dan organisasi. Tangerang: UI Press.

Oliver, A. L., \& Rothmann, S. (2007). Antecendent of work engagement in a multinational oil company. SA Journal of Industrial Psychology, 33(3), 40-56.

Robbins, S. P. \& Judge, T. A. (2011). Perilaku organisasi: Organizational behavior. Jilid 1. (12 $2^{\text {th }}$ ed). Jakarta: Salemba Empat.

Robbins, S. P. \& Judge, T. A. (2011). Perilaku organisasi: Organizational behavior. Jilid 2. (12 $2^{\text {th }}$ ed). Jakarta: Salemba Empat.

Robinson, I. (2006). Human resouce management in organization. London, England: CIPD

Rosso, B. D., Dekas, K. H., \& Wrzesniewski, A. (2010). On the meaning of work: A theoretical integration and review. Research in Organizational Behavior, 1(30), 94-120.

Rothmann, S. (2010). Factor associated with employee engagement in South Africa. $S A$ Journal of Industrial Psychology, 36(2), 1-12.

Rothmann, S. \& Welsh, C. (2013). Employee engagement: The role of psychological conditions. Management Dynamics, 22(1), $1-120$.

Rothmann, S. (2013). Callings, work role fit, psychological meaningfulness and work engagement among teachers in Zambia. South African Journal of Education, 33(2), 1-16.

Rusnawati, V. (2013). Peran kepemimpinan kepala sekolah dalam upaya meningkatkan disiplin kerja guru pada SDN 018 Balikpapan. Jurnal Administrasi Negara, 1(2),1-19.

Saks, A. M. (2006). Employee engagement: Antecendents and consequences. Journal of Managerial Psychology, 1(21), 600-619.

Schaufeli, W. B., \& Bakker, A. B. (2004). Job demands, job resources, and their relationship with burnout and engagement: A multi-sample study. Journal of Organizational Behavior, 1(25), 410-427.

Schaufeli, W. B. (2012). Work engagement. What do we know and where do we go?. Journal of Applied Psychology,14(01), 3-10.

Schaufeli, W. B., Martinez, I. M., Pinto, A. M., Salanova, M., \& Bakker,A. B. (2002a). Burnout and engagement in university students: Across-national study. Journal of Cross-Cultural Psychology, 1(33), 464481.

Schaufeli, W. B., Martinez, I. M., Pinto, A. M., Salanova, M., \& Bakker, A. B. (2002). The Measure of engagement and burnout: A confirmative analysis approach. Journal of Happines Studies, 3(1), 701-716.

Schaufeli, W. \& Bakker, A. (2003). Utrecht work engagement scale, Preliminary Manual Version 1. Occupational Health Psychology Unit.

Schaufeli, W. B. \& Bakker, A. B. (2009). How changes in job demands and resources predict burnout, work engagement, and sickness absentieeism. Journal of Organizational Behavior, 1(30), 1-15. 
Schaufeli, W. B. \& Salanova, M. (2007). Work engagement: an emerging psychological concept and its implication for organization. Managing Social and Ethnical Issue in Organization, 1(5), 78-90.

Schueller, S. \& Seligman,M. (2010). Pursuit of pleasure, engagement, and meaning: Relationship to subjective and objective measures of well-being. The Journal of Positive Psychology, 5(4), 1-17.

Schultz, D. \& Schultz, S. E. (1990). Employee Psychology and industry today: An introduction to industrial and organizational psychology ( $5^{\text {th }}$ ed.). New York, NY: Maxwell MacMillan.

Steer, R. M \& Porter, L. W. (1983). Motivation and work behaviour ( $3^{\text {rd }}$ ed.). New York, NY: McGraw-Hill.

Steger, M. F. \& Dik, B. J. (2009). If one is searching for meaning in life, does meaning in work help? Journal of Applied Psychology: Health and Well-Being, 1(1), 301-320.
Steger, M. F., Dik, B. J. \& Duffy, R.D. (2012). Measuring meaningful work: The work and meaning inventory (WAMI). Journal of Career Assessment, 1(0), 1-16.

Sungkit, F. N. (2014). Pengaruh job enrichment terbadap employee engagement melalui psychological meaningfulness sebagai mediator. Thesis (Unpublished). Yogyakarta: Magister Profesi Psikologi Universitas Gadjah Mada.

Taniredja, T. \& Mustafidah, H. (2012). Penelitian kuantitatif. Bandung: Alfabeta.

Van Zyl, L. E., Deacon, E., \& Rothmann, S. (2010). Towards happiness: Experiences of work-role fit, meaningfulness and work engagement of industrial organizational psychologists in South Africa. $S A$ Journal of Industrial Psychology, 36(1), 1-14.

Wolf, S. (2010). Meaning in life and why it matters. Princeton, NJ: University Press. 